\title{
Automatic Photometric Titration Procedure Based on Multicommutation and Flow-Batch Approaches Employing a Photometer Based on Twin LEDs
}

\author{
Milton B. da Silva, ${ }^{a}$ Carla C. Crispino ${ }^{a}$ and Boaventura F. Reis*,b \\ ${ }^{a}$ Departamento de Química, Universidade Federal de São Carlos, São Carlos-SP, Brazil \\ ${ }^{b}$ Centro de Energia Nuclear na Agricultura, Universidade de São Paulo, \\ Av. Centenario 303, 13400-970 Piracicaba-SP, Brazil
}

\begin{abstract}
Neste trabalho, é descrito um fotômetro de baixo custo baseado em um par de LEDs idênticos, empregando um, como fonte de luz e o outro como fotodetector. $\mathrm{O}$ equipamento, incluindo o fotômetro e o módulo de análises, foi projetado para implementar um procedimento de titulação automático empregando o processo de multicomutação por injeção em fluxo (MCFIA). O sistema proposto dispunha de meios para realizar a titulação fotométrica sem a necessidade de empregar curva analítica. A utilidade foi comprovada analisando amostras de vinagre e sucos de limão, laranja, abacaxi, maracujá e cajú. A exatidão foi verificada comparando os resultados com outros, obtidos empregando procedimento manual, e não foi observada diferença significativa no nível de confiança de $95 \%$. Amostras com diferentes concentrações de ácido, tais como suco de limão $\left(1.084,73 \mathrm{mmol} \mathrm{L}^{-1}\right)$ e suco de abacaxi $\left(14,42 \mathrm{mmol} \mathrm{L}^{-1}\right)$ foram tituladas usando a mesma solução titulante, e sem modificação do sistema de titulação.
\end{abstract}

In this work, a reliable and inexpensive photometer based on twin LEDs assembled as a radiation source and as a photodetector is described. The setup including the photometer and flow system module was designed to implement an automated titration procedure employing the multicommuted flow injection analysis (MCFIA) process. The proposed system was able to carry out photometric titration without using analytical curve to achieve the sample concentration. Its usefulness was proven by analyzing vinegar and lemon, orange, pineapple, maracock, and acajou juices. Accuracy was accessed comparing results with those obtained employing a manual procedure and no significant difference was observed at $95 \%$ confidence level. Samples presenting different acid concentrations such as lemon juice $\left(1084.73 \mathrm{mmol} \mathrm{L}^{-1}\right)$ and pineapple juice $\left(14.42 \mathrm{mmol} \mathrm{L}^{-1}\right)$ could be titrated using the same titration solution without any modification of the titrating setup.

Keywords: multicommuted flow injection analysis, flow-bath analysis, automated photometric titration, fruit juice, LED photometer

\section{Introduction}

The light emitting diode (LED) was utilized for the first time as a radiation source for photometric detection by Flaschka et al. ${ }^{1} 35$ years ago, and afterwards by D. Betteridge et al. ${ }^{2}$ After these pioneer studies, the use of LEDs with an analytical purpose increased continuously, and today we can see that several analytical procedures employing LED as a radiation source have been published..$^{3-6}$ Small size, low cost, high stability of the radiation beam, and long lifetime are the main features of LEDs which explains its widespread use in different

\footnotetext{
*e-mail: reis@cena.usp.br
}

analytical procedures. ${ }^{7-9}$ The availability of LEDs with wavelengths ranging from ultraviolet ( $\lambda c a .380 \mathrm{~nm}$ ) to near infrared ( $\lambda c a .900 \mathrm{~nm})$ also is an additional incentive for the development of the LED based photometers. ${ }^{10-12}$ Although equipment for fluorimetric detection has also been designed employing a LED as a radiation source, ${ }^{13,14}$ photometers predominate by far. The LED small size and fast response when it is switched on and off has allowed its application to flow analysis-based analytical procedures for the simultaneous determination of two or more analytes ${ }^{15,16}$ and chemical speciation. ${ }^{2,17}$

There are a few studies on the use of LEDs as photodetectors. ${ }^{8,19}$ The measurement was done using the LED capacitance effect, which presents a relationship 
between capacitor discharge time and the intensity of the light beam illuminating the LED employed as a photodetector. This effect occurred when the wavelength of the light beam was identical to that of the photodetector LED. The detection was carried out considering as the measurement parameter, the time interval elapsed while the potential difference at the LED decreased from $5 \mathrm{~V}$ to $1.7 \mathrm{~V}$.

Recently, Tymecki and co-workers ${ }^{20,21}$ showed that a LED acting as a photodetector generated a difference of electric potential proportional to the intensity of the light illuminating it. Aiming to prove that a LED could be a reliable photodetector, assays were carried out using solutions of $\mathrm{Fe}^{\mathrm{III}}$ and $\mathrm{Co}^{\mathrm{II}}$ complexes with $\mathrm{SCN}^{-} .{ }^{20}$ A more detailed study concerning the LED response as a photodetector was performed using a single-line flow injection manifold and promothymol blue solutions as a model. ${ }^{21}$ In both cases, the measurements were taken using a common potentiometric $\mathrm{pH}$-meter.

In this work, we intend to develop a dedicated setup for photometric titration employing twin LEDs. The device designed involved coupling one LED as a radiation source to a detector LED in a transduction network with two operational amplifiers. Aiming to prove the setup applicability, a full automated titration procedure was developed. The flow system module was designed combining the flow bath ${ }^{22,23}$ and the multicommutation approaches..$^{24,25}$

\section{Experimental}

\section{Reagent solutions}

Purified water with conductivity of less than $0.1 \mathrm{mS} \mathrm{cm} \mathrm{cm}^{-1}$ was used throughout. A sodium hydroxide solution ( $\left.c a .0 .1 \mathrm{~mol} \mathrm{~L}^{-1}\right)$ was prepared by appropriated dilution from a $10 \mathrm{~mol} \mathrm{~L}^{-1} \mathrm{NaOH}$ stock solution and standardized by titration using a potassium biphthalate solution and a $0.01 \%(\mathrm{~m} / \mathrm{v})$ phenolphthalein solution as an indicator. Vinegar samples, and pineapple and acajou juices were purchased at the local market. The juices were centrifuged before use. Lemon, orange, and maracock juices were prepared before use by squeezing fresh fruits using a manual juicer. The juices were filtered to remove solid particles.

\section{Apparatus}

The equipment setup comprised the lab-made LEDbased photometer as described below; a microcomputer furnished with a PCL711S electronic interface card
(PCL711S, Advantech Corp, Cincinnati, OH, USA); an IPC-8 Ismatec peristaltic pump with Tygon pumping tube; one 225P091-11 pinch solenoid valve and four 161T031 three-way solenoid valves (Nresearch, New Jersey, USA); one lab-made interface ${ }^{9}$ to power the solenoid valves; a $12 \mathrm{~V}$ mini-motor; a regulated power supply $(-12 \mathrm{~V},+12 \mathrm{~V})$ to power the LED-based photometer; an acrylic titration chamber as detailed below, two identical (twin) high brightness $5 \mathrm{~mm}$ LEDs (intensity of $10000 \mathrm{mcd}$ ) with maximum emission at $\lambda=531 \mathrm{~nm}$, and view angle of $15^{\circ}$; and a two-operational amplifier (OP07).

\section{Titration chamber and photodetector assembling}

Figure 1 shows a cutaway of the titration chamber. The glass cylinders ( $\mathrm{gc}$ ) conducted the radiation beam emitted by $\mathrm{LED}_{1}$ to the titration chamber and from this up to $\mathrm{LED}_{2}$. Figure 2 shows the electronic diagram of the photometer. $\mathrm{LED}_{1}$ was wired as a radiation source and the intensity of the radiation beam was adjusted by means of a variable resistor $(10 \mathrm{~kW})$ wired to the base of a transistor (Tr). $\mathrm{LED}_{2}$ was coupled to an operational amplifier $\left(\mathrm{A}_{1}\right)$ to work as a photodetector. The signal $\mathrm{S}_{0}(\mathrm{mV})$ at the operational amplifier $\left(\mathrm{A}_{2}\right)$ output presented a closed relationship with the intensity of the radiation beam emitted by $\mathrm{LED}_{1}$. The generate signal $\left(\mathrm{S}_{0}\right)$ was monitored by a microcomputer through the analog input of a PCL711S interface card. When titration was carried out, the radiation beam crossed the solution in the titration chamber and was absorbed. The radiation intensity attenuation was sensed by the signal transducer network constituted by $\mathrm{LED}_{2}$ and the operational amplifier $\left(\mathrm{A}_{1}\right)$. This feature was employed to develop the photometric titration procedure.

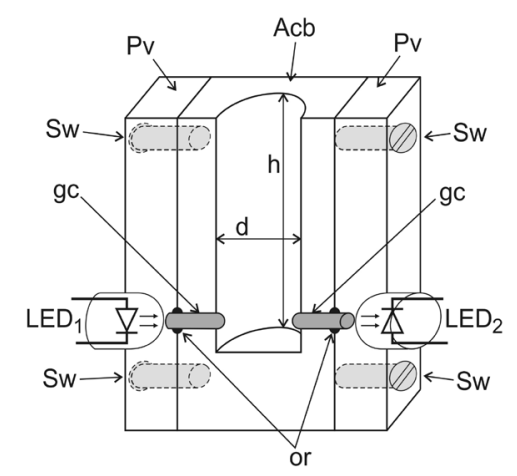

Figure 1. Cutaway of the titartion chamber. $\mathrm{Pv}=\mathrm{PVC}$ plates, dimension $50 \mathrm{~mm}$ high, $40 \mathrm{~mm}$ wide and $15 \mathrm{~mm}$ tickness; $\mathrm{Acb}=$ acrylic block with dimension, $50 \mathrm{~mm}$ high, $40 \mathrm{~mm}$ wide and $24 \mathrm{~mm}$ tickness; $\mathrm{Sw}=$ screw; $\mathrm{gc}=$ glass cylinders, $3 \mathrm{~mm}$ diameter and $15 \mathrm{~mm}$ long; $\mathrm{h}$ and $\mathrm{d}=$ eight $(30 \mathrm{~mm})$ and diamenter $(8 \mathrm{~mm})$ of the hole perforated in the acrylic block to comprise the titartin chamber; and or = sealing gasket. $\mathrm{LED}_{1}$ and $\mathrm{LED}_{2}=$ radiation source and photodector, respectively. 


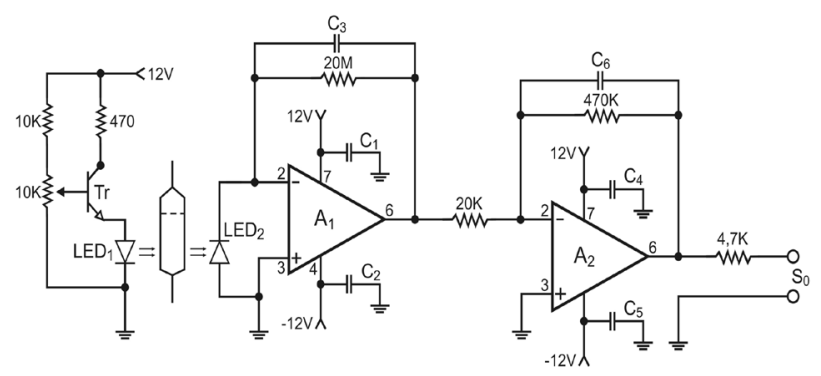

Figure 2. Electronic diagram of the photometric detection unit. $\mathrm{Tr}=$ transistor $\mathrm{BC} 547 \mathrm{LED}_{1}$ and $\mathrm{LED}_{2}=$ green light emitting diode, $\lambda_{\text {max }}=531 \mathrm{~nm} ; \mathrm{A}_{1}$ and $\mathrm{A}_{2}=\mathrm{OP} 07$ operational amplifier; $\mathrm{C}_{1}, \mathrm{C}_{2} \mathrm{C}_{4}$ and $\mathrm{C}_{5}=$ tantalum capacitors, $2 \mu \mathrm{F} ; \mathrm{C}_{3}$ and $\mathrm{C}_{6}=$ polyester capacitors, $5 \mathrm{nF}$ and $0.47 \mu \mathrm{F} ; \mathrm{S}_{0}=$ output signal (mv). Resistors in $\mathrm{W}$.

\section{Flow system functioning and photometer calibration}

The flow system diagram is shown in Figure 3. In this configuration, all valves are switched off; thus, all solutions are pumped back to their storage recipients. When the control software was run, the microcomputer carried out the titration procedure following the sequence depicted in Table 1. As shown in Figure 1, the $3.0 \mathrm{~mm}$ diameter glass cylinders (gc) were installed $1.0 \mathrm{~mm}$ from the bottom of the titration chamber, and the mixing bar (mb, Figure 3) was placed $c a .2$ mm over the glass cylinders. To ensure efficient mixing, it was established that a $7 \mathrm{~mm}$ high water column should be maintained into the titration chamber. Since the inner diameter of the titration chamber was $8.0 \mathrm{~mm}$, a water volume of $360 \mu \mathrm{L}$ was always inserted into the titration chamber prior titration.

The photometer calibration indicated in the second step was performed by reading the dark measurement $(\mathrm{Sd})$, which was carried out with $\mathrm{LED}_{1}$ off. This measurement value $(c a .10 \mathrm{mV})$ was used to calculate the absorbance. Afterwards, the intensity of the radiation beam emitted by $\mathrm{LED}_{1}$ was adjusted in order to obtain a potential difference of $1200 \mathrm{mV}$ at the output of the operational amplifier $\left(\mathrm{A}_{2}\right)$. This adjustment was carried out by means of the variable resistor wired to the base of the transistor (Tr). This step was performed at the software start. As the photometer output signal (Figure 2) was negative, it was converted to positive for the calculation of the absorbance by software.

After the calibration step, the microcomputer carried out the titration following the sequence of steps shown in Table 1. Because pumping pulsation could affect the precision of the solution volumes inserted into the titration chamber, a synchronization step was carried out prior

Table 1. Sequence of the titration procedure

\begin{tabular}{|c|c|c|c|c|c|c|c|c|c|c|}
\hline Step & Event & $\mathrm{V}_{1}$ & $\mathrm{~V}_{2}$ & $\mathrm{~V}_{3}$ & $\mathrm{~V}_{4}$ & $\mathrm{~V}_{5}$ & $\mathrm{Mm}$ & time/s & $\begin{array}{c}\text { Flow Rate/ } \\
\left(\mu \mathrm{L} \mathrm{s}^{-1}\right)\end{array}$ & $\begin{array}{c}\text { Volume/ } \\
\mu \mathrm{L}\end{array}$ \\
\hline 1 & Insertion water into titration chamber & 0 & 0 & 0 & 1 & 0 & 0 & 12 & 30 & 360 \\
\hline 2 & Calibration of photometer & 0 & 0 & 0 & 0 & 0 & 0 & - & - & - \\
\hline 3 & Empty chamber & 0 & 0 & 0 & 0 & 1 & 0 & 8 & 45 & - \\
\hline 4 & Insertion water into titration chamber & 0 & 0 & 0 & 1 & 0 & 0 & 12 & 30 & 300 \\
\hline 5 & Insertion of sample solution & 1 & 0 & 0 & 0 & 0 & 0 & 4.0 & 12.02 & 48.08 \\
\hline 6 & Insertion of day indictor solution & 0 & 0 & 1 & 0 & 0 & 0 & 2.0 & 11.2 & 22.40 \\
\hline 7 & Mixing solutions & 0 & 0 & 0 & 0 & 0 & 1 & 2.0 & - & - \\
\hline 8 & Reading of reference signal (Rs) & 0 & 0 & 0 & 0 & 0 & 0 & 2.0 & - & - \\
\hline 9 & Insertion of titrant solution and reads signal & 0 & 1 & 0 & 0 & 0 & 1 & $\Delta \mathrm{t}_{1}$ & 12.32 & $\mathrm{~V}_{\mathrm{T} 1}$ \\
\hline 10 & Mixing solutions & 0 & 0 & 0 & 0 & 0 & 1 & 3.0 & - & - \\
\hline 11 & Read signal (S) & 0 & 0 & 0 & 0 & 0 & 0 & - & & - \\
\hline 12 & Insertion of sample solution• & 1 & 0 & 0 & 0 & 0 & 1 & $\Delta \mathrm{t}_{2}$ & 6.01 & $\mathrm{~V}_{\mathrm{s} 2}$ \\
\hline 13 & Mixing solutions $\bullet$ & 0 & 0 & 0 & 0 & 0 & 1 & 2.0 & - & - \\
\hline 14 & Read signal (S) • & 0 & 0 & 0 & 0 & 0 & 0 & - & - & - \\
\hline 15 & Insertion of titrant solution & 0 & 1 & 0 & 0 & 0 & 1 & $\Delta \mathrm{t}_{3}$ & 6.16 & $\mathrm{~V}_{\mathrm{T} 2}$ \\
\hline 16 & Mixing solutions & 0 & 0 & 0 & 0 & 0 & 1 & 3.0 & - & - \\
\hline 17 & Read signal (S) & 0 & 0 & 0 & 0 & 0 & 0 & - & - & \\
\hline 18 & Empty chamber & 0 & 0 & 0 & 0 & 1 & 0 & 20 & 45 & \\
\hline 19 & Washing chamber with water & 0 & 0 & 0 & 1 & 0 & 1 & 20 & 30 & 600 \\
\hline 20 & Empty chamber & 0 & 0 & 0 & 0 & 1 & 0 & 15 & 45 & - \\
\hline
\end{tabular}

The number 0 and 1 indicated that the corresponding device is switched OFF or ON, respectively. The labels $\bullet$ and $\bullet$ indicate that these events could be repeated, and for detail see text. 


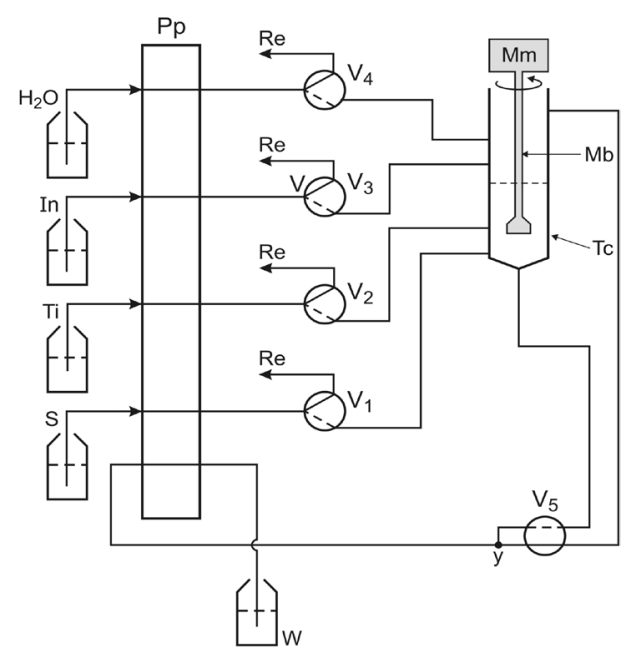

Figure 3. Diagram of the flow system. Ti $=$ titrant solution $(\mathrm{NaOH})$; $\mathrm{S}=$ sample solution; $\mathrm{H}_{2} \mathrm{O}=$ carrier solution, flow rate at $37.85 \mathrm{~mL} \mathrm{~s}^{-1}$; In = dye indicator solution; $\mathrm{V}_{1}, \mathrm{~V}_{2}, \mathrm{~V}_{3}$ and $\mathrm{V}_{4}=$ three-way solenoid valves; $\mathrm{Re}=$ solution circulation; $\mathrm{y}=$ joint device machined in acrylic, $\mathrm{Tc}=$ titration chamber; $\mathrm{Mb}=$ magnetic stirring bar; $\mathrm{Mm}=\mathrm{DC}$ mini-motor; $\mathrm{Pp}=$ peristaltic pump; $\mathrm{W}=$ waste. The solid and dashed lines into the valves symbols indicate the fluid pathway when valves were OFF or ON, respectively; and arrows indicate the direction of the solutions streams.

to inserting each solution. This task was done reading the roller count signal generated by the peristaltic pump through the analog input of the PCL711 interface card.

\section{General procedure}

As is indicated in Table 1, steps 4, 5, and 6 were carried out to insert water, sample, and indicator solution aliquots into the titration chamber. After mixing (step 7), the reference signal (Rs) was read (step 8). Afterwards, valve $\mathrm{V}_{2}$ was switched on to insert the titration solution into the titration chamber (step 9). When the read signal became higher than the preset threshold ( 0.5 absorbance), valve $\mathrm{V}_{2}$ was switched off in order to direct the titration solution stream to its storage vessel. The signal read (S) at step 11 was used to calculate the absorbance using the equation: Absorbance $\mathrm{A}=-\log [(\mathrm{S}-\mathrm{Sd}) /(\mathrm{Rs}-\mathrm{Sd})]$, where $\mathrm{Sd}$ is the dark measurement obtained in the photometer calibration step. The software was instructed to end the titration when Ref $\leq \mathrm{A} \leq 2$ Ref. The Ref value was maintained at $0.15 \mathrm{~A}$. The sets of steps 12, 13 and 14; 15, 16 and 17 comprised the fine adjustment, which was carried out using low flow rates $\left(c a .6 \mu \mathrm{L} \mathrm{s}^{-1}\right)$ as was indicated in Table 1. The pumping flow rate was controlled by the microcomputer through the serial interface RS232. Under this condition, the values of the timer intervals $\mathrm{Dt}_{2}$ and $\mathrm{Dt}_{3}$ were selected by software, as indicated in Table 2, which was done considering the relationship between the Ref value and the absorbance related to the last measurement. At steps 3, 18 and 20, valve
$\mathrm{V}_{5}$ was switched on to empty the titration chamber in order to abbreviate the washing step.

Table 2. Time intervals to insert sample and titrant solution

\begin{tabular}{lccc}
\hline $\begin{array}{l}\text { Ref. Signal } \\
(\mathrm{A})\end{array}$ & $\begin{array}{c}\text { Read Signal } \\
(\mathrm{A})\end{array}$ & $\begin{array}{c}\text { Sample insertion } \\
\Delta \mathrm{t}_{2} / \mathrm{s}\end{array}$ & $\begin{array}{c}\text { Titrant solution } \\
\text { insertion } \Delta \mathrm{t}_{3} / \mathrm{s}\end{array}$ \\
\hline 0.3 & $\mathrm{~A}>1$ & 2.0 & - \\
0.3 & $0.7<\mathrm{A} \leq 1$ & 0.5 & - \\
0.3 & $0.45<\mathrm{A} \leq 0.7$ & 0.2 & - \\
0.3 & $0.3<\mathrm{A} \leq 0.45$ & 0.1 & - \\
0.15 & $0.15>\mathrm{A}>0.1$ & - & 0.1 \\
0.15 & $0.1 \leq \mathrm{A}<0.3$ & - & 0.2 \\
0.15 & $0.03 \leq \mathrm{A}<0.1$ & - & 0.5 \\
\hline
\end{tabular}

The assays to verify if the LED could be used as a photometric device, as well as to establish the optimum operating condition, was carried out using $0.1 \mathrm{~mol} \mathrm{~L}^{-1} \mathrm{HCl}$ and $\mathrm{NaOH}$ solutions. To prove the applicability of the proposed setup, a set of samples including vinegar and juices of pineapple, acajou, lemon, orange, and maracock were titrated using standardized sodium hydroxide solutions. Samples were also titrated employing a manual procedure for assessment of accuracy.

\section{Results and Discussion}

\section{The performance of the photodetector LED}

Previous assays carried out using a sodium hydroxide solution and phenolphthalein as a day indicator, showed that the visual perception of the pink color was associated with an absorbance of $c a$. 0.15 . Considering the results achieved by titrating hydrochloride acid solution using a sodium hydroxide solution, we established that titration could be ended when absorbance was within the range from 0.15 to 0.30 . In this sense, after steps 4 to 11 (Table 1) had been carried out, the microcomputer performed the titration fine adjustment by varying the volumes of the solution aliquots using the time intervals and flow rates as depicted in Table 2.

As was reported by Tymecki and co-workers ${ }^{20,21}$ in a recent study, the signal generated by the LED wired as a photodetector increases with the electric current intensity. Therefore, the generated difference of potential $\left(\mathrm{S}_{0}\right)$ was the parameter used to monitor light absorption as a function of the electric current intensity, yielding the results shown in Table 3. The absorbance did not vary significantly in multiple repetitions, as shown in this table. Considering these results, the output signal (Figure 2) was adjusted to $1200 \mathrm{mV}$ at the photometer calibration (Table 1, step 2). 
Table 3.The LED response as a photodetector varying the light beam intensity

\begin{tabular}{lcc}
\hline Sample & Signal $/ \mathrm{mV}$ & Absorbance \\
\hline Water & $498.21 \pm 4.93$ & - \\
Sodium hydroxide & $250.73 \pm 2.69$ & $0.3071 \pm 0.0042$ \\
Water & $780.49 \pm 10.92$ & - \\
Sodium hydroxide & $385.12 \pm 5.73$ & $0.3125 \pm 0.0048$ \\
Water & $1155.64 \pm 11.72$ & \\
Sodium hydroxide & $565.40 \pm 6.42$ & $0.3144 \pm 0.0039$ \\
Water & $1452.94 \pm 13.77$ & \\
Sodium hydroxide & $721.15 \pm 6.18$ & $0.3072 \pm 0.0032$ \\
Water & $1747.29 \pm 20.98$ & - \\
Sodium hydroxide & $846.83 \pm 10.67$ & $0.3172 \pm 0.0045$ \\
\hline
\end{tabular}

Results are average of five consecutive measurements.

\section{Effect of the initial sample volume}

As shown in Table 1, the titration run began by inserting an initial sample volume into the titration chamber. Considering that the volume of the first sample aliquot could affect the precision of the results, a set of assays was carried out by varying the time interval to determine the conditions that would maintain valve $\mathrm{V}_{1}$ switched on at step 5 (Table 1). The results are given in Table 4. The initial sample aliquot varied from 24.40 to $195.20 \mathrm{~mL}$. The final sample solution volume was obtained summing the initial volume and those obtained for the time interval $\mathrm{Dt}_{2}$ (Table 1) and the related flow rate. The final titrant solution volume was calculated using time intervals $\mathrm{Dt}_{1}$ and $\mathrm{Dt}_{3}$ (Table 1) and the corresponding flow rates. The average $\mathrm{HCl}$ concentration was estimated at $89.14 \pm 1.16 \mathrm{mmol} \mathrm{L}^{-1}$; therefore, indicating that the precision of the results did not depend on the initial sample volume.

\section{Sample analysis}

To demonstrate the effectiveness of the proposed photometric titration setup, a set of vinegar and fruit juice samples was analyzed employing the manifold showed in Figure 3 and the operating conditions in Table 1. The results are shown in Table 5. Samples 1 to 6,7 to 17 and 14 to 19 were titrated using sodium hydroxide solutions with concentrations of 95.7, 98.5, and $94.2 \mathrm{mmol} \mathrm{L}^{-1}$, respectively.

Accuracy was accessed by applying the paired $t$-test. The tabulated value was $\mathrm{t}_{(0.05)}=1.4558$ and the value found was 0.1573 , thus not indicating any significant difference at $95 \%$ confidence level. Except for the samples indicated with an asterisk, which were diluted 10 times with water, the samples were titrated without previous dilution, yielding concordant results. Comparing the results for samples numbers 8 and 11, we can observe that the acid concentration of lemon juice was 84 times higher than that of acajou juice. Both titrations were made using the same titrant solution $\left(98.5 \mathrm{mmol} \mathrm{L}^{-1} \mathrm{NaOH}\right)$; thus proving that the system was able to select the appropriate time intervals to maintain valves $\mathrm{V}_{1}$ and $\mathrm{V}_{2}$ (Figure 3) switched on for the insertion of the sample and titrant solution aliquots into the titration chamber. The results shown in Table 5 were obtained analyzing the sample at three days. As can be observed, accuracy and precision were maintained, therefore indicating that the overall performance of the system was very good. This could be considered as an indication that a LED is a reliable photometric device for analytical purposes.

The volumes of sample and titrant solution aliquots were a function of both the time interval to maintain valves $\mathrm{V}_{1}$ and $\mathrm{V}_{2}$ switched on and the pumping flow rates of the sample and titrant solution. The precision of the time

Table 4. Titration performance varying the initial sample volume

\begin{tabular}{|c|c|c|c|c|c|}
\hline Sample & Titration run & Initial volume $/ \mu \mathrm{L}$ & Sample Final volume $/ \mu \mathrm{L}$ & Titrant Final volume $/ \mu \mathrm{L}$ & Found concentration $/\left(\mathrm{mmol} \mathrm{L}^{-1}\right)$ \\
\hline \multirow[t]{8}{*}{$\mathrm{HCl}$} & 1 & 24.40 & 37.02 & 39.60 & $88.25 \pm 1.27$ \\
\hline & 2 & 48.80 & 58.18 & 61.98 & $87.89 \pm 1.40$ \\
\hline & 3 & 73.20 & 78.61 & 86.79 & $91.08 \pm 1.51$ \\
\hline & 4 & 97.60 & 98.98 & 107.56 & $89.65 \pm 0.82$ \\
\hline & 5 & 122.00 & 140.68 & 153.28 & $89.88 \pm 0.91$ \\
\hline & 6 & 146.40 & 164.61 & 176.62 & $88.52 \pm 1.05$ \\
\hline & 7 & 170.80 & 183.40 & 197.87 & $88.91 \pm 0.98$ \\
\hline & 8 & 195.20 & 204.61 & 220.65 & $88.96 \pm 0.92$ \\
\hline
\end{tabular}

Results are average of five consecutive measurements. The titration was carried out using a $82.5 \mathrm{mmol} \mathrm{L}^{-1}$ standardized sodium hydroxide solution. 
Table 5. Results comparison

\begin{tabular}{|c|c|c|c|c|c|}
\hline \multicolumn{2}{|c|}{ Sample } & \multirow{2}{*}{$\begin{array}{c}\text { Titrant/Sample }\left(\mathrm{V}_{\mathrm{T}} / \mathrm{V}_{\mathrm{S}}\right) \\
0.7859 \pm 0.0107\end{array}$} & \multirow{2}{*}{$\begin{array}{c}\text { Found } /\left(\mathrm{mmol} \mathrm{L}^{-1}\right) \\
75.21 \pm 0.95\end{array}$} & \multirow{2}{*}{$\frac{\text { Reference } /\left(\mathrm{mmol} \mathrm{L}^{-1}\right)}{76.81 \pm 1.53}$} & \multirow{2}{*}{$\begin{array}{c}\text { Ratio/(\%) } \\
97.92\end{array}$} \\
\hline 1 & Apple vinegar* & & & & \\
\hline 2 & Apple vinegar & $7.9451 \pm 0.2012$ & $760.35 \pm 18.24$ & $749.45 \pm 11.24$ & 101.5 \\
\hline 3 & Red wine* vinegar & $0.7836 \pm 0.0118$ & $74.99 \pm 1.24$ & $73.55 \pm 0.68$ & 101.9 \\
\hline 4 & Red wine vinegar & $7.7899 \pm 0.1481$ & $745.49 \pm 15.12$ & $761.52 \pm 19.10$ & 97.9 \\
\hline 5 & Rice vinegar ${ }^{*}$ & $0.8571 \pm 0.0172$ & $82.02 \pm 1.25$ & $83.21 \pm 1.45$ & 98.6 \\
\hline 6 & Rice vinegar & $8.7895 \pm 0.1741$ & $841.16 \pm 11.21$ & $818.12 \pm 24.51$ & 102.8 \\
\hline 7 & Lemon juice ${ }^{*}$ & $1.1074 \pm .0133$ & $109.08 \pm 1.75$ & $104.31 \pm 1.83$ & 104.5 \\
\hline 8 & Lemon juice & $11.1251 \pm 0.0215$ & $1084.73 \pm 22.71$ & $1092.45 \pm 24.32$ & 99.3 \\
\hline 9 & Lemon juice* & $1.0239 \pm 0.0123$ & $100.85 \pm 1.21$ & $97.51 \pm 1.67$ & 103.4 \\
\hline 10 & Lemon juice & $10.3025 \pm 0.1371$ & $1014.78 \pm 14.12$ & $998.74 \pm 26.92$ & 101.6 \\
\hline 11 & Acajou juice & $0.1328 \pm 0.0022$ & $12.51 \pm 0.17$ & $11.93 \pm 0.19$ & 104.8 \\
\hline 12 & Orange juice & $1.0541 \pm 0.0301$ & $103.82 \pm 2.59$ & $104.32 \pm 2.11$ & 99.5 \\
\hline 13 & Orange juice & $1.0991 \pm 0.0195$ & $108.26 \pm 1.98$ & $104.21 \pm 1.82$ & 103.9 \\
\hline 14 & Pineapple juice & $0.1444 \pm 0.0019$ & $13.29 \pm 0.28$ & $12.46 \pm 0.19$ & 106.7 \\
\hline 15 & Pineapple juice & $0.1531 \pm 0.0021$ & $14.42 \pm 0.23$ & $14.73 \pm 0.17$ & 97.8 \\
\hline 16 & Acajou juice & $0.1496 \pm 0.0027$ & $14.10 \pm 0.26$ & $14.32 \pm 0.29$ & 98.0 \\
\hline 17 & Orange juice & $1.4311 \pm 0.0216$ & $140.96 \pm 1.69$ & $143.28 \pm 1.72$ & 98.5 \\
\hline 18 & Maracock juice & $5.7832 \pm 0.0685$ & $544.78 \pm 6.59$ & $538.13 \pm 10.22$ & 101.2 \\
\hline 19 & Maracock juice & $5.2751 \pm 0.0693$ & $496.91 \pm 6.46$ & $482.68 \pm 5.31$ & 102.9 \\
\hline
\end{tabular}

Results of the proposed procedure are average of 5 consecutive titrations, while results of manual procedure are related to 3 titrations. The label $*$ indicated that the sample was diluted ten times with water from the next one.

interval was related to the microcomputer performance, thus attention was given to the pumping flow rates, which were determined daily prior to beginning the work. No significant variation was observed, demonstrating that a pair of pumping tubes could be used for one week.

\section{Conclusions}

Working continuously for $4 \mathrm{~h}$, no significant measurement variation was observed, thus we can conclude that the long-term stability of the proposed twin LED photometer is very good. This assay was repeated one day per week for two months, and the results had similar precision. We concluded that the use of twin LEDs as a photometric transducer for photometric titration is reliable.

Samples of lemon juice presenting acid concentration 84 times higher than that of acajou juice were titrated using the same titration solution without any modification of the titrating setup. This feature could be considered as an advantage comparing with titration earlier procedures based on flow-bath approach, ${ }^{21,26}$ where the range of the acid concentration in the samples was around one tenth. These results allow us to conclude that the software was able to find the appropriated pathway to carry out the titration.

\section{Acknowledgments}

Authors acknowledge CNPq (Conselho Nacional de Desenvolvimento Científico e Tecnológico do Brasil) and CAPES (Coordenadenação de Aperfeiçoamento de Pessoal de Nível Superior) for the financial support and Grant to Milton B. Silva and Carla C. Crispino.

\section{References}

1. Flaschka, H.; Mckeithan, C.; Barnes, R.; Anal. Lett. 1973, 6, 585.

2. Betteridge, D.; Dagless, E. L.; Fields, B.; Graves, F.; Analyst 1978, 103, 897.

3. Dasgupta, P. K.; Bellamy, H. S.; Liu, H. H.; Lopez, J. L.; Loree, E. L.; Talanta 1993, 40, 53.

4. Ellis, P. S.; Lyddy-Meaney, A. J.; Worsfold, P. J.; McKelvie, I. D.; Anal. Chim. Acta 2003, 499, 81.

5. Dasgupta, P. K.; In-Yong, E.; Morris, K. J.; Jianzhong, Li.; Anal. Chim. Acta 2003, 500, 337.

6. Jambunathan, S.; Dasgupta, P. K.; Wolcott, D. K.; Marshall, G. D.; Olson, D. C.; Talanta 1999, 50, 481.

7. Yonehara, F. S.; Pasquini, C.; Jarbas, J. R. R.; J. Braz. Chem. Soc. 2005, 16, 928.

8. Karthikeyan, S.; Kajiya, S. H. T. K.; Hirata, S.; Anal. Bioanal. Chem. 2004, 378, 1842. 
9. Rodenas-Torralba, E.; Rocha, F. R. P.; Reis, B. F.; MoralesRubio, A.; de la Guardia, M.; J. Autom. Methods Manage. Chem. 2006, Article ID 20384.

10. Fonseca, A.; Raimundo, I. M.; Anal. Chim. Acta 2005, 522, 223.

11. Araújo, M. C. U.; Santos, S. R. B.; Silva, E. A.; Veras, G.; Lima, J. L. F. C.; Lapa, R. A. S.; Quim. Nova 1997, 20,137.

12. Feres, M. A.; Reis, B. F.; Talanta 2005, 68, 422.

13. Muller, M., Hauser, P. C.; Analyst 1996, 121, 339.

14. Zang, T.; Fang, S. Q.; Wang, L.; Qin, L. F.; Wang, P.; Wu, Z. Y.; Fang, Z. L.; Talanta 2005, 68,19.

15. Fernandes, R. N.; Reis, B. F.; Talanta 2002, 58, 729.

16. Luca, G. C.; Reis, B. F.; Spectrochim. Acta, Part A 2004, 60, 579.

17. Rocha, F. R. P.; Reis, B. F.; Anal. Chim. Acta 2000, 409, 227.

18. Lau, K. T.; Baldwin, S.; L.Shepherd, R.; Dietz, P. H.; Yerzunis, W. S.; Diamond, D.; Talanta 2004, 63,167.
19. O’Toole, M.; Lau, K. T.; Shepherd, R.; Slater, C.; Diamond, D.; Anal. Chim. Acta 2004, 597, 290.

20. Tymecki, L.; Pokrzywnicka , M.; Koneki, R.; Analyst 2008, $133,1501$.

21. Tymecki L.; Roncki, R.; Anal. Chim. Acta 2009, 639, 73.

22. Honorato, R. S.; Araujo, M. C. U.; Lima R. A. C.; Zagatto, E. A. G.; Lapa, R. A. S.; Lima, J. L. F. C.; Anal. Chim. Acta 1999, 396, 91.

23. da Silva, M. J.; dos Anjos, E. V.; Honorato, R. S.; Pimentel, M. F.; Paim, A. P. S.; Anal. Chim. Acta 2008, 629, 98.

24. Lavorante, A. F.; Feres, M. A.; Reis, B. F.; Spectrosc. Lett. 2006, $39,631$.

25. Rocha, F. R. P.; Infante, C. M. C.; Melchert, W. R.; Spectrosc. Lett. 2006, 39, 651.

26. Garcia, A. J. C.; Reis, B. F.; J. Autom. Methods Manage. Chem. 2006, Article ID 83247; DOI 10.1155/JAMMC/2006/83247.

Submitted: October 10, 2009

Published online: June 18, 2010

FAPESP has sponsored the publication of this article. 